JWL

$26,3 / 4$

232

Received 12 September 2013

Revised 31 December 2013

Accepted 4 February 2014

\section{Does corporate social responsibility impact on employee engagement?}

Pedro Ferreira and Elizabeth Real de Oliveira

Faculty of Business and Economics, Lusiada University, Vila Nova de Famalicao, Portugal

\begin{abstract}
Purpose - Despite the claim that internal corporate social responsibility plays an important role, the understanding of this phenomenon has been neglected. This paper intends to contribute to fill this gap by looking into the relation between CSR and employee engagement.

Design/methodology/approach - A survey research was conducted and three different groups of respondents were faced with three different CSR scenarios (general, internal, external) and respondents' employee engagement was measured.

Findings - The results show that there are no statistically significant differences in levels of engagement between employees exposed to external and internal CSR practices. Nevertheless, employees exposed to internal CSR are more engaged than those exposed only to external CSR practices.
\end{abstract}

Research limitations/implications - The use of scenarios, although a grounded approach, involves risks, including the difficulty of participants to put themselves in a fictional situation. Also, the scale used to measure employee engagement puts the emphasis on work rather than on the organisation.

Practical implications - Although this study is not conclusive it raises the need for companies to look at their CSR strategy in a holistic approach, i.e. internal and external.

Originality/value - This paper represents a contribution to understand CSR strategic status and the need to enlighten the impact that social responsible practices can have on employees' engagement.

Keywords Corporate social responsibility, Employee engagement, CSR, Internal CSR, External CSR, Utrecht Work Engagement Scale

Paper type Research paper

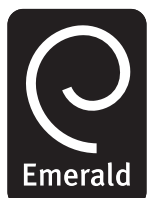

Journal of Workplace Learning Vol. 26 No. $3 / 4,2014$ pp. $232-248$ (C) Emerald Group Publishing Limited 1366-5626

DOI 10.1108/JWL-09-2013-0070

\section{Introduction}

Corporate social responsibility (CSR) has been in the spotlight in the last decades. The challenges, derived from new technology and fast paced market changes posed to organisations, and a new, more informed consumer, raised the bar regarding how companies should behave towards stakeholders, including social, economic and environmental concerns (Garavan and McGuire, 2010). On the other hand, employees are increasingly questioning the meaning of their work, and companies that fail to realise this will face problems in attracting, retaining and engaging the best employees (Bhattacharya et al., 2008).

The work reported in this paper was co-financed by FCT (PEst-OE/EME/UI4005/2011) and carried out within the research centre Centro Lusíada de Investigação e Desenvolvimento em Engenharia e Gestão Industrial (CLEGI). 
CSR has been viewed and treated within different disciplines, such as business ethics, marketing and business and management studies (Cooke and He, 2010). However, this interest has been focused on issues such as performance (Rettab et al., 2009), strategy (McWilliams et al., 2006), marketing and consumer behaviour (Sen and Bhattacharya, 2001; Real de Oliveira and Rodrigues, 2012), neglecting the importance of human resources. Nevertheless it has been proven that employee buy-in is a key factor in ensuring engagement with CSR (Davies and Crane, 2010). Al-bdour et al. (2010) state that failure in understanding the impact of CSR on employee's attitude and behaviour, will lead to faulty conclusions misleading researchers and practitioners towards considerations regarding the utility or impact of CSR.

The development of employee engagement and the enhancing and detracting factors are understudied in empirical and theoretical studies (Saks, 2006). Moreover the antecedents and outcomes of employee engagement are conceptualised in just a few models (Shuk and Wollard, 2010). This paper intends to contribute towards the understanding of the antecedents of employee engagement by emphasising the role of CSR.

The pertinence of this relationship is already recognised by practitioners. According to David Saul "it's no surprise that employees tend to be happier at companies offering high pay and a generous holiday allowance, but the diversity of the Sunday Times survey is recognition that creating a great working environment requires more than this" (HR Magazine online October 12 2012). Forbes Magazine, in an article published in January 201218 named The Top 10 Trends in CSR for 2012, points as the number 3 trend "Employee Engagement Emerges" where it is stated that the connection between this two fields continues to grow. The article mentions a study undertaken by A Hewitt \& Associates covering 230 workplaces and reaching more than 100,000 employees. The findings were that the more a company actively engages in CSR practices, the more engaged their employees are. Also, results from a study produced by the Society for Human Resources Management (SHRM) show that companies with sustainability programs have higher numbers of employee morale and loyalty. This is even more important when, according to a report made by the Gallup Institute (2013), only 13 per cent of employees across 142 countries worldwide are engaged in their job.

The purpose of this paper is to study the relationship of CSR and engagement. Does CSR functions as an antecedent of engagement? If so, what kinds of CSR practices are more relevant to engagement? Those concerning internal or external stakeholders?

The theoretical framework for this study will be supported in the Social Identity Theory (Tajfel and Turner, 1985) and the Stakeholders Theory (Freeman, 1984) since recent theory suggests that stakeholder management is aligned with organisational identity (Brickson, 2005; Scott and Lane, 2000).

According to Tajfel and Turner (1985) there is an individual need to classify oneself and others into social groups, thus deriving part of their identity from the group(s) to which they belong. Within this context belonging to a group, and sharing common goals, can help to explain employees' behaviours, perceptions and feelings. Thus CSR as a common goal might enhance engagement. Moreover, when organisations invest in building relationships with their stakeholders, they are more likely to be successful (Lindgreen and Swaen, 2010), since employees as a stakeholder group perceive,

\section{Does CSR impact on employee engagement?}

233

233


JWL $26,3 / 4$

\section{4}

evaluate, judge and react to CSR programs and actions (Rowley and Berman, 2000; Rupp et al., 2006; Wood and Jones, 1995).

\section{Corporate social responsibility}

There are many CSR definitions and this concept has been studied in various scientific fields. Aguilera et al. (2007) use a definition of CSR which refers to "the firm's considerations of, and response to, issues beyond the narrow economic, technical, and legal requirements of the firm to accomplish social [and environmental] benefits along with the traditional economic gains which the firm seeks" (apud Davis, 1973, p. 312). The Commission of the European Communities (2001, p. 4) defined CSR as "a concept whereby companies integrate social and environmental concerns in their business operations and in their interaction with their stakeholders on a voluntary basis". Kotler and Lee (2005, p. 3) defined CSR as "the commitment to improve community well-being through discretionary business practices and contributions of corporate resources".

In other words we can state that CSR can be defined as policies and practices that organisations engage regarding creating positive social, including environmental, changes aimed at different stakeholders. It is important to note that this is a voluntary approach.

The links between CSR and HRM have been explored in the literature by several authors (Gond and Igalens, 2011; Rettab et al., 2009; Shen, 2011; Wojtaszczyk, 2008; Young and Thyil, 2009; Buciuniene and Kazlauskaite, 2012; Cooke and He, 2010; Fuentes-Garcia and Nunez-Tabales, 2008; Preuss and Haunschild, 2009; Shen and Zhu, 2011).

Real de Oliveira et al. (2013) undertook a systematic literature review regarding this relationship. They have attempted to identify if CSR was treated in the literature as part of the HR function or if embedded in the sustainability agenda. From their work four literature clusters emerged, namely CSR and HRM, Strategy and Performance, Ethics and Sustainability and Ethics in HRM. Some of the HR areas that emerged in this review were employee related issues (e.g. Wojtaszczyk, 2008; Davies and Crane, 2010), responsible leadership (e.g. Gond and Igalens, 2011), and the HR function (e.g. Shen, 2011, Buciuniene and Kazlauskaite, 2012).

The concept of stakeholders is central to CSR (Maon et al., 2009). According to Hansen et al. (2011) research on CSR has tended to focus on external stakeholders and outcomes, rather than focusing on the internal aspects that relate CSR and firm performance and its impact on internal stakeholders, such as employees. Actually, the categorisation of stakeholders can assume several perspectives depending on the approach. Kakabadse et al. (2005) identified some of the most common categorisations such as primary/secondary stakeholders, voluntary/involuntary stakeholders, social/non-social stakeholders and intrinsic, definitional and instrumental stakeholders. However, the most common categorisation is the internal vs external stakeholders, which will hold the approach of this research.

CSR has internal and external dimensions. Internal CSR practices refer to CSR practices which are directly related with the physical and psychological working environment of employees (Turker, 2009). It is expressed in concern for the health and well-being of employees (Wojtaszczyk, 2008), their training and participation in the business (Brammer et al., 2005), equality of opportunities (Newman and de Vries, 2011), work-family relationship (Marchese and Bassham, 2002). 
On the other hand, we can state that external CSR refers to corporate socially responsible actions directed outside its boundaries, such as actions directed to local community, business partners and suppliers, customers, public authorities and NGOs (Al-bdour et al., 2010).

\section{Employee engagement}

The concept of employee engagement is relatively recent. It was first coined by the Gallup Group, as a result of several empirical works based on interviewing and surveying managers and employees from around the world. This term has gained considerable popularity in the past 20 years yet remaining inconsistently defined and conceptualised with little rigorous academic research done (Shuk and Wollard, 2010). Actually, it is easy to understand why the increase in popularity, since the outcomes of employee engagement can be exactly what most organisations need. When employees are engaged they will be more productive, and profitable, also they will be less likely to be absent, and more willing to work harder for their companies (Buchanan, 2004; Fleming and Asplund, 2007; Wagner and Harter, 2006). Vance (2006) also suggests that engaged employees generate higher customer satisfaction ratings and increased revenue.

However, in parallel with the increase of the term's popularity, a challenge is raised. What is employee engagement and how it should be defined? (Macey and Schneider, 2008). According to Little and Little (2006), this construct presents several problems, which they address, including the absence of clarification of the relationship between engagement and other well-known and accepted constructs, namely organisational commitment and job or work involvement.

Employee engagement is sometimes mistaken with commitment and involvement, mainly due to interchangeable use of the expressions, some considering it even as a repacking of these expressions (Schneider et al., 2005). Although they all refer to a positive attachment to work, engagement, commitment and involvement are conceptually distinct. Job involvement stresses the cognitive and psychological identification with work, and includes the idea that work satisfies needs and expectations (Kanungo, 1979). On the other hand, commitment is more related with attitudinal and affective aspects that stress the emotional attachment based on shared values and interests with the organisation.

The first definition of engagement found in the academic literature is the one from Kahn (1990, p. 700) that defines personal engagement as "the simultaneous employment and expression of a person's 'preferred self' in task behaviours that promote connections to work and to others, personal presence, and active full role performances". Following this work, other authors such as Maslach et al. (2001), Harter et al. (2003), Saks (2006) and Czarnowsky (2008) have contributed towards the clarification of an employee engagement definition.

For the purpose of this paper our preferred definition is the one provided by Bakker and Schaufeli (2008) that states that work engagement can be defined as a positive, fulfilling, affective-motivational state of work-related well-being. In fact, engagement has emanated from the positive psychology that stresses the need to investigate and find effective applications of positive traits, states and behaviours of employees within organisations (Bakker and Schaufeli, 2008). As such, engagement can be considered the antipode of burnout (Maslach et al., 2001).

\section{Does CSR impact on employee engagement?}

235 
JWL $26,3 / 4$

236
In theoretical terms, although with a common root, the concepts are clearly distinct. In empirical terms, Hallberg and Schaufeli (2006) investigated the differences in a sample of Information and Communication Technology consultants and also found empirical evidence to support the difference between work engagement, involvement and commitment.

Saks (2006) distinguishes job engagement and organisation engagement. Drawing from Kahn's (1990) seminal research, engagement is conceptualised as role related, reflecting the extent to which an individual is psychologically present in a particular organisational role. Thus, the two most dominant roles for most organisational members are their work role and their role as a member of an organisation. In his research, he found that job and organisation engagement are different, not only because the scores were different, but their relationship with antecedents and consequences were also distinct. Although job and organisation engagements had impact in job satisfaction, organisational commitment, intention to quit, and organisational citizenship behaviour of the organisation, organisation engagement was a much stronger predictor of all of the outcomes than job engagement. Finally, job characteristics predicted job engagement and procedural justice predicted organisation engagement.

The measurement of employee engagement is also bone of contention among scholars. Viljevac et al. (2012) investigated the validity of two measures of work engagement (the Utrecht Work Engagement Scale (UWES) and the May, Gilson and Harter scale) that have emerged in the academic literature. They found some evidence for convergent, discriminant and predictive validity for both scales, although neither showed discriminant validity with regard to job satisfaction. They contend that important differences in measuring engagement raises questions on how to measure the construct and the results will be specific to the measures used, limiting generalisation.

As mentioned before, another measure was developed by Saks (2006) that distinguishes job and organisation engagement. The construct validity is assessed by factor analysis that showed the two factors - job and organisation engagement.

However, the UWES is one of the most used construct to measure engagement. Schaufeli et al. (2002), p. 74) defines work engagement as "a positive, fulfilling, work-related state of mind that is characterised by vigour, dedication, and absorption". The construct has been used in several contexts and countries (e.g. Schaufeli et al., 2002; Petrou et al., 2012; Ouweneel et al., 2012; Bakker et al., 2007; Salanova and Schaufeli, 2008; Salanova et al., 2005; Chung and Angeline, 2010).

The construct comprises three dimensions. Vigour refers to the levels of energy, mental resilience and persistence. Dedication is about the mental and emotional state that reflects on experience a sense of significance, enthusiasm, inspiration and pride. Finally, absorption means being completely concentrated in ones work.

\section{Corporate social responsibility and employee engagement}

Although there is a wide range of literature addressing CSR and its linkages with the role and practices of $\mathrm{HR}$ few empirical studies addressed the relation between CSR and Employee Engagement. This is probably due to the recency of the concept of employee engagement as demonstrated previously in this research paper. 
Some studies have been conducted regarding the relation of CSR practices and its relationship with the employees increase of identification and commitment to the organisation, organisational citizenship behaviours and meaningfulness of work (Aguilera et al., 2007; among others).

Other studies refer that CSR could also enhance firms' ability to attract and keep top talent (Bhattacharya et al., 2008).

The studies found that refer this two constructs (CSR and Employee Engagement) addressed mainly stakeholder engagement (Greenwood, 2007), viewed as corporate social responsibility in action (Tamm et al., 2010) and the contribution of CSR for employee buy-in regarding the use of HR (selection and socialisation in particular) in the context of small and medium sized enterprises (Davies and Crane, 2010).

Some companies view employee engagement in CSR as a "strategic imperative" (Bhattacharya et al., 2008), nevertheless, according to the same author, few if none, know how to reap the returns of such CSR engagement.

Mirvis (2012, p. 113) raises a number of questions regarding CSR and Employee Engagement, namely, "does engagement through CSR follow simply from being a part of a company known for its social responsibility? The benefits to self-esteem and image can be potent; you work for a 'good' company! Or does it require actually doing something socially responsible on one's job? Can volunteerism substitute for putting CSR to work on the job? Vice-versa? And what about psychic gains from participating in a CSR effort while working for a 'bad' company?".

This lack of evidence in empirical studies, points out to a gap of theoretical consolidation on how and why CSR impacts on employees' attitudes and behaviour (Gond and Igalens, 2011), namely regarding the construct we intend to analyse.

From the literature review a gap related to the relationship between employee engagement and different CSR contexts was identified (Figure 1). In order to study this relationship regarding CSR being an antecedent of employee engagement, we use the Schaufeli et al. (2002) definition and measurement of employee engagement.

The following research hypotheses are raised.

H1. Employee engagement presents statistically different levels when exposed to different CSR contexts

H1.1. Employee engagement is higher among employees exposed to internal CSR

H2. Vigour presents statistically different levels statistically different levels when exposed to different CSR contexts

H2.1. Vigour is higher among employees exposed to internal CSR

H3. Dedication presents statistically different levels statistically different levels

\section{CSR Contexts}

Internal CSR

External CSR
Does CSR impact on employee engagement?

237 
JWL $26,3 / 4$

\section{8}

when exposed to different CSR contexts

H3.1. Dedication is higher among employees exposed to internal CSR

H4. Absorption presents statistically different levels when exposed to different CSR contexts

H4.1. Absorption is higher among employees exposed to internal CSR

\section{Methods}

The goal of this study is to examine the influence of CSR on employee engagement. Specifically, we try to understand how different forms of CSR can influence workers' engagement with their organisation.

We defined three levels of CSR that were presented to respondents as scenarios. The use of scenarios is common within the experimental methods to study consumers' reactions and attitudes. In several studies CSR was manipulated by creating different levels of corporate ethics, which allowed to test respondents' attitudes and behaviour towards companies with more or less ethical and social responsible practices (Sen and Bhattacharya, 2001; Ferreira et al., 2010). The results from these experimental studies point out to the impact that CSR information can have on behavioural intentions, as well as companies' and products' evaluation.

Following previous research three scenarios were set up to illustrate three different companies: the first scenario described a company that only fulfils their legal obligations regarding environment and human resources; the second scenario described a company as having social responsible practices towards external stakeholders, such as suppliers and the community where they operate; finally, the third scenario described the company as having social responsible practices towards their workforce, namely the concern with employees' well-being. Table I shows the description of the scenarios as they were presented to respondents.

Employee engagement was measured using the short version of the Utrecht Work Engagement Scale (UWES) (Schaufeli et al., 2006), using a seven-point Likert scale $(1=$ Not probable; $7=$ Most probable). The UWES is widely used as a reliable construct of work engagement. In fact, as seen on the literature review, several studies use this construct (Schaufeli et al., 2002; Petrou et al., 2012; Ouweneel et al., 2012; Bakker et al., 2007; Salanova and Schaufeli, 2008; Salanova et al., 2005; Chung and Angeline, 2010). Among these, the study by Schaufeli et al. (2006) involving more than 14,000 employees of ten countries confirmed the UWES construct and validated a short version of the UWES comprising nine of the initial 17 items.

Although smaller, this version kept the initial three dimensions: vigour (e.g. "At my work, I feel bursting with energy”), dedication (e.g. "I am enthusiastic about my job”), and absorption (e.g. "I feel happy when I am working intensely") (see Table II).

A few studies report the use of the UWES scale in Portugal. Schaufeli et al. (2002) used the scale to research students' burnout and engagement, adapting the UWES scale to the goal and population of the study. The scale was translated to Portuguese from the Spanish version, not from the original. Salanova et al. (2011) used only two of the three dimensions, meaning they did not use the full version of the scale. Moreover, there is no mention to translation procedures or to the use of Schaufeli's previous translation. 
Scenario 1 - "No CSR"

Scenario 2 - "External oriented CSR"

Scenario 3 - "Internal oriented CSR"
Imagine working for a company that is on the market for about 30 years, with a solid and sustained growth. This company's philosophy is based on the principle of fulfilling all of their legal obligations. Being an SME, has always been concerned with the surrounding community, with employees, showing particular attention to the environmental impact of their activity

In addition to the environmental concerns arising from legal compliance, this company has a social responsibility policy that covers, for example, the purchase of raw material from suppliers who share the same ethical values or support to non-governmental organizations working with children. More recently they launched a campaign in which a percentage of the price of the final product reverts to social responsibility actions selected by consumers Although recent years have been difficult due to the economic crisis, this company is making an effort to follow the philosophy of its founder, namely the concern for the wellbeing of employees. In this sense, the company has a nursery for the children of employees and a canteen at controlled prices since its founding. In recent years they broadened the social support including a partnership with a company of domestic services. Furthermore, the recruitment and selection policies give priority to the integration of people with disabilities

\section{Does CSR impact on employee engagement?}

239

Table I.

CSR scenarios
VI1

VI2

DE2

DE3

VI3

AB3

DE4

$\mathrm{AB} 4$

AB5

\author{
At my work, I feel bursting with energy \\ At my job, I feel strong and vigorous \\ I am enthusiastic about my job \\ My job inspires me \\ When I get up in the morning, I feel like going to work \\ I feel happy when I am working intensely \\ I am proud of the work that I do \\ I am immersed in my work \\ I get carried away when I am working
}

Table II.

UWES short version items

Since neither of previous studies fitted the purpose of this research, we developed our own translation procedures. First, the items were translated to Portuguese and then were subjected to back translation procedures. The results were very good, meaning that the Portuguese translation kept intact the meaning of the original items. Then, we pre-tested the scale to detect possible misunderstandings.

The sample was extracted from middle managers of several of the major private companies in Portugal, including companies from different sectors, such as finance, telecoms, food and beverages, and retail. For the purpose of this study we decided to include only middle managers because, although they were facing a scenario, not a real situation, they are more sensible to the organisational context and nuances. The sample procedure was non-random and the identification of participants was by convenience, since respondents were invited by e-mail to answer the questionnaire. Total sample comprised 236 observations.

Preliminary analysis of normality and outliers allowed the elimination of 43 observations, due to the presence of extreme values in all the UWES items. The final sample has a total of 193 observations and distribution among the three scenarios is as 
JWL $26,3 / 4$ follows: 84 (43.5 per cent) observations for "no CSR" scenario; 58 (30.1 per cent) observations for "external CSR" scenario; and 51 (26.4 per cent) for "internal CSR" scenario. The sample is made of 59.1 per cent men and 40.9 per cent were women. The average age of respondents is 38 years old $(\mathrm{SD}=8,738)$.

Data was collected using a questionnaire with three sections: the first section presented the scenario, the second section measured work engagement and the third section comprises demographic variables. Respondents were asked to answer the questionnaire as if they worked in the company described in the scenario provided. The sample was divided in three sub-samples: sub-sample 1 answered the questionnaire with the "no CSR" scenario; sub-sample 2 answered the "basic CSR with external CSR" scenario; and group 3 answered the "basic CSR with internal CSR" scenario.

Since the goal of the study was to examine the CSR influence on employee engagement, data analysis was based on statistical procedures to compare groups. Once the factor variable (CSR scenario) presents three different groups, we used the Oneway between-groups ANOVA with post hoc tests. The UWES construct and its three dimensions were tested using data reduction techniques, namely confirmatory factor analysis (EFA), with principal components analysis as the extraction method. This procedure is suitable for confirming the structure of the construct since it needed to be validated for the Portuguese context.

\section{Data analysis}

The analysis starts by presenting the results for all the nine UWES items. In general, the mean scores for all the items are quite high and the majority is well above 5, showing a general high level of respondents engagement with the company's scenarios presented. Three items present scores above 5.5, namely "At my work, I feel bursting with energy" $(M=5.62)$, "I am enthusiastic about my job" $(M=5.62)$ and "I am proud of the work that I do" $(M=5.72)$. Again, two out of three of the higher rated items are part of the "dedication" dimension. On the opposite, three items score around 5, namely "I feel happy when I am working intensely" $(\mathrm{M}=5.19)$, "When I get up in the morning, I feel like going to work" ( $M=5.18)$ and "I get carried away when I am working" $(M=5.08)$, being two of them from the Absorption dimension.

When comparing scenarios, the results are very similar and there is not a clear pattern. However, the "internal CSR" scenario has the highest mean scores on six out of nine items, especially on the Vigour dimension. The "no CSR" scenario presents the lowest values on two items. Also, the "no CSR" scenario presents general higher scores than "external CSR" on several items, especially on Vigour. When comparing, "external CSR" with "internal CSR" scenarios, the latter has systematically higher scores on all items, with the exception of three items (1 Absorption and 2 Dedication items), namely "I am enthusiastic about my job", "I feel happy when I am working intensely", and "I am proud of the work that I do".

The next step of the analysis was to examine the UWES construct. For that purpose we performed a Confirmatory Factor Analysis (CFA) in order to look for higher order factors, namely those found by Schaufeli et al. (2006).

The Bartlett test of sphericity does not accept the null hypothesis that the correlation matrix is an identity matrix (Chi-square $=1276.892 ; \mathrm{df}=36$; $\mathrm{Sig} .=0.000$ ) and the KMO test $(0.926)$ points to the presence of common factors, indicating the 
sample is adequate for the factor analysis. The items presented high loadings, above 0.65 , and the result of the factor analysis points out to three factors (Eigenvalue $=7.242 ; \mathrm{PVAF}=80.466$ per cent). These results do confirm the construct structure proposed by Schaufeli et al. (2006).

The scale reliability, given by the Cronbach Alpha, is high for Vigour $(\alpha=0.833)$, Dedication $(\alpha=0.868)$, and Absorption $(\alpha=0.886)$. The descriptive statistics are presented in Table III. Dedication scores higher than any other dimension in all scenarios, while Absorption scores lower. Vigour is higher on internal CSR $(M=5.46)$, and Dedication has higher mean scores on the no CSR and external CSR scenarios (see Table IV).

Using the factor score as variable (saved using the Regression Method) we went on to examine potential differences between the three scenarios. For this purpose, a

\begin{tabular}{|c|c|c|c|c|c|c|c|}
\hline & & $n$ & Mean & SD & Minimum & Maximum & \\
\hline \multirow{4}{*}{$\begin{array}{l}\text { VI1 - At my work, I feel bursting } \\
\text { with energy }\end{array}$} & S1(CSR & 84 & 5,60 & 0,995 & 3 & 7 & \\
\hline & S2 External CSR & 58 & 5,55 & 1,095 & 3 & 7 & \\
\hline & S3 Internal CSR & 51 & 5,73 & 0,896 & 3 & 7 & \\
\hline & Total & 193 & 5,62 & 0,999 & 3 & 7 & \\
\hline \multirow{4}{*}{$\begin{array}{l}\text { VI2 - At my job, I feel strong and } \\
\text { vigorous }\end{array}$} & S1(CSR & 84 & 5,23 & 1,068 & 1 & 7 & \\
\hline & S2 External CSR & 58 & 5,16 & 1,073 & 3 & 7 & \\
\hline & S3 Internal CSR & 51 & 5,35 & 0,955 & 3 & 7 & \\
\hline & Total & 193 & 5,24 & 1,038 & 1 & 7 & \\
\hline \multirow[t]{4}{*}{ DE2 - I am enthusiastic about my job } & S1(CSR & 84 & 5,64 & 1,049 & 2 & 7 & \\
\hline & S2 External CSR & 58 & 5,66 & 1,001 & 3 & 7 & \\
\hline & S3 Internal CSR & 51 & 5,55 & 0,832 & 3 & 7 & \\
\hline & Total & 193 & 5,62 & 0,977 & 2 & 7 & \\
\hline \multirow[t]{4}{*}{ DE3 - My job inspires me } & S1(CSR & 84 & 5,29 & 1,071 & 2 & 7 & \\
\hline & S2 External CSR & 58 & 5,41 & 1,060 & 2 & 7 & \\
\hline & S3 Internal CSR & 51 & 5,41 & 0,898 & 3 & 7 & \\
\hline & Total & 193 & 5,36 & 1,021 & 2 & 7 & \\
\hline VI3 - When I get up in the morning, & S1(CSR & 84 & 5,18 & 1,088 & 1 & 7 & \\
\hline \multirow{3}{*}{ I feel like going to work } & S2 External CSR & 58 & 5,07 & 1,168 & 2 & 7 & \\
\hline & S3 Internal CSR & 51 & 5,29 & 0,807 & 3 & 6 & \\
\hline & Total & 193 & 5,18 & 1,046 & 1 & 7 & \\
\hline \multirow{4}{*}{$\begin{array}{l}\text { AB3 - I feel happy when I am working } \\
\text { intensely }\end{array}$} & S1(CSR & 84 & 5,21 & 1,141 & 1 & 7 & \\
\hline & S2 External CSR & 58 & 5,24 & 1,247 & 1 & 7 & \\
\hline & S3 Internal CSR & 51 & 5,08 & 1,129 & 1 & 7 & \\
\hline & Total & 193 & 5,19 & 1,167 & 1 & 7 & \\
\hline \multirow[t]{4}{*}{ DE4 - I am proud of the work that I do } & $\mathrm{S} 1$ (CSR & 84 & 5,71 & 1,093 & 2 & 7 & \\
\hline & S2 External CSR & 58 & 5,76 & 1,048 & 2 & 7 & \\
\hline & S3 Internal CSR & 51 & 5,69 & 1,049 & 3 & 7 & \\
\hline & Total & 193 & 5,72 & 1,063 & 2 & 7 & \\
\hline \multirow[t]{4}{*}{ AB4 - I am immersed in my work } & S1(CSR & 84 & 5,23 & 1,090 & 1 & 7 & \\
\hline & S2 External CSR & 58 & 5,31 & 1,245 & 1 & 7 & \\
\hline & S3 Internal CSR & 51 & 5,31 & 0,948 & 3 & 7 & \\
\hline & Total & 193 & 5,27 & 1,100 & 1 & 7 & \\
\hline \multirow{4}{*}{$\begin{array}{l}\text { AB5 - I get carried away when I am } \\
\text { working }\end{array}$} & S1(CSR & 84 & 5,07 & 1,149 & 1 & 7 & Table III. \\
\hline & S2 External CSR & 58 & 4,98 & 1,132 & 1 & 6 & Descriptive statistics for \\
\hline & S3 Internal CSR & 51 & 5,20 & 0,939 & 3 & 7 & employee engagement by \\
\hline & Total & 193 & 5,08 & 1,089 & 1 & 7 & CSR scenario \\
\hline
\end{tabular}

Does CSR impact on employee engagement?

241

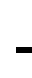


JWL

\begin{tabular}{llrrr}
\hline Scenarios & & Vigour & Dedication & Absorption \\
\hline S1 & & & & \\
No CSR & Mean & 5,33 & 5,55 & 5,17 \\
& Median & 5,33 & 5,67 & 5,33 \\
& Mode & 6,00 & 6,00 & 6,00 \\
S2 & Std dev. & 0,9096 & 0,9395 & 1,0080 \\
External CSR & & & 5,61 & 5,18 \\
& Mean & 5,26 & 6,00 & 5,67 \\
& Median & 5,67 & 6,00 & 6,00 \\
& Mode & 6,00 & 0,9390 & 1,1381 \\
S3 & Std dev. & 0,9854 & 5,55 & 5,20 \\
Internal CSR & & & 5,67 & 5,33 \\
& Mean & 5,46 & 6,00 & 6,00 \\
& Median & 5,67 & 0,8349 & 0,8697 \\
\hline & Mode & 5,67 & &
\end{tabular}

Table IV.

242

UWES short version descriptive statistics one-way between-groups analysis of variance was conducted to explore the impact of CSR scenarios on work engagement, as measured by the UWES, followed by post hoc tests to identify which differences between which groups. Subjects were divided into three groups according to three scenarios (Group 1: no CSR; Group 2: external CSR; Group 3: internal CSR). The Levene's test score confirm that data for Dedication $($ Sig. $=0.922)$ and Absorption (Sig. $=0.231$ ) does not violate the assumption of homogeneity of variance. However, data for Vigour (Sig. $=0.010$ ) was violating this assumption, which imply reading the Welch Robust Test of Equality of Means. The results of the ANOVA show a not significant difference at the $p<0.05$ level in Dedication $[F(2,190)=0.91, p=0.913]$ and Absorption $[F(2,190)=0.10, p=0.990]$ dimensions of UWES scores for the three CSR scenarios. Also, the results of the Welch test did not reveal a significant difference between the scenarios $[F(2,190)=0.685$, $p=0.505]$.

The general results show that, statistically, there is no difference in employee engagement when facing different CSR situations. This is not consistent with previous research that demonstrates the linkage between CSR practices and HR practices and outputs (Gond and Igalens, 2011; Rettab et al., 2009; Shen, 2011; Wojtaszczyk, 2008; Young and Thyil, 2009; Buciuniene and Kazlauskaite, 2012; Cooke and He, 2010; Fuentes-Garcia and Nunez-Tabales, 2008; Preuss and Haunschild, 2009; Shen and Zhu, 2011).

Even though, we examined the mean differences between groups and CSR scenarios as reported in Figure 2. The mean scores differences are quite small, but with the exception of dedication, the work engagement dimensions mean scores are higher in the internal CSR scenario. Thus, although the differences are not statistically significant it does not mean that CSR has no influence whatsoever in work engagement.

\section{Conclusions}

The goal of this study was to examine if CSR influences employee engagement and specifically, if different forms of CSR impact differently on employee engagement. Employee engagement was measured using the UWES. The main conclusion is that, 


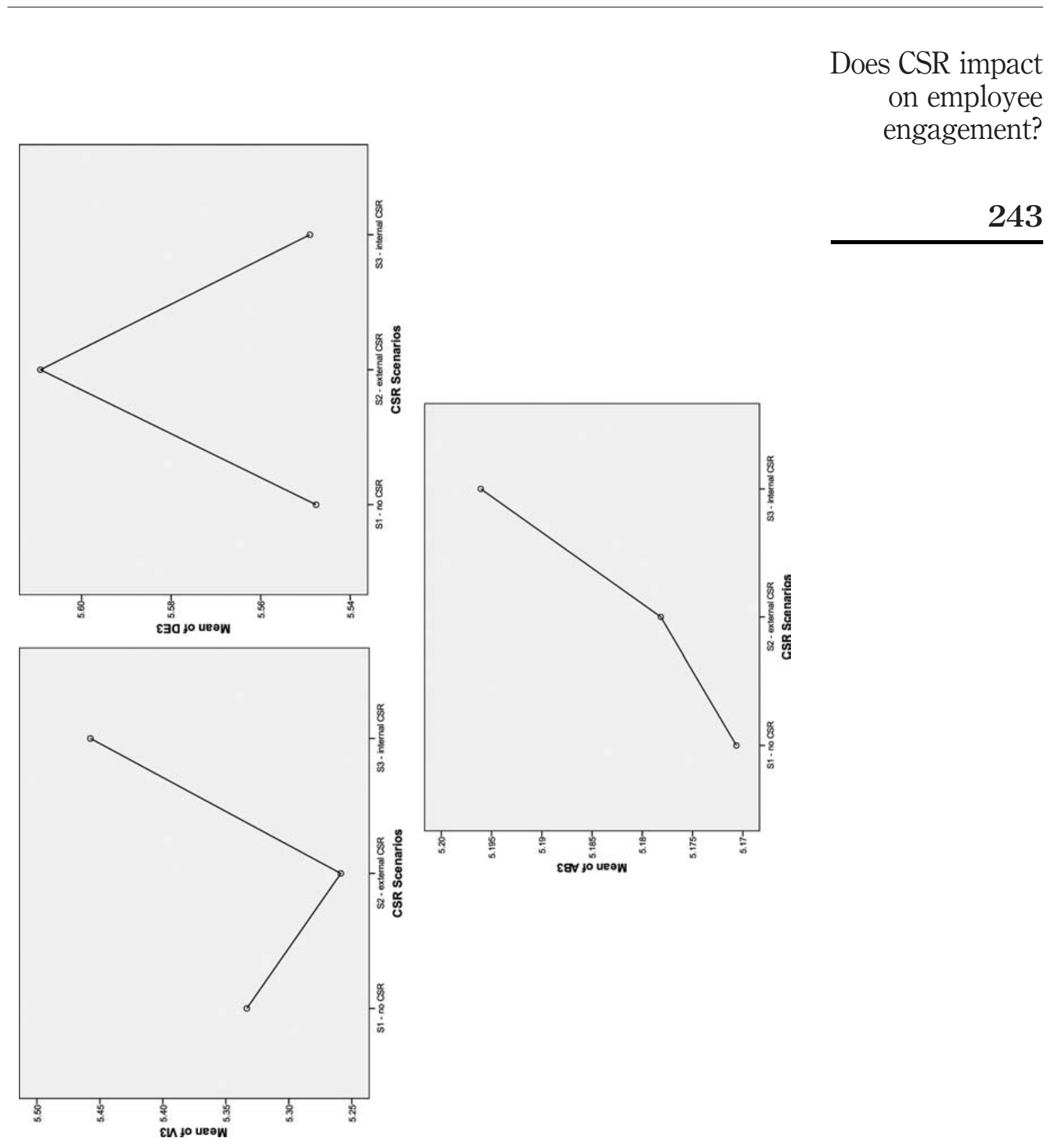

Figure 2.

Mean scores for vigour, dedication and absorption by scenarios 
JWL $26,3 / 4$

244 although engagement is generally high among respondents, there is no significant difference between different forms of CSR, namely internal and external forms.

The empirical approach was based on a confirmatory factor analysis that resulted in three factors, confirming the structure of the construct proposed by Schaufeli et al. (2006); the Cronbach's alpha also confirmed the high internal consistency. However, the ANOVA did not confirm a statistically significant difference between groups.

Although the assumption that CSR policies and practices oriented to employees can boost engagement is not statistically supported, it is not denied by data. In fact, the differences between internal and external CSR are quite visible when considering engagement or when decomposing the construct into three dimensions proposed by the UWES. In either case, internal CSR seems to promote more engagement than external CSR, especially driving to more vigour and absorption.

The use of scenarios was the basis of the methodological approach to the problem, thus playing an important role for the course of the research. In the lack of real situations and for the purpose of establishing comparisons, scenarios are an interesting approach, allowing respondents to put themselves in face of specific situations. Nevertheless, this option involves risks, including the difficulty of participants to put themselves in a fictional situation. The respondents' sample maybe considered another limitation, since companies were chosen by convenience and respondents were drawn from different companies with different backgrounds, which may have influenced data.

Another limitation is related to the scale used to measure engagement. Although the validity of the UWES is not in dispute, this scale puts the emphasis on work rather than on the organisation. As Saks (2006) suggests, work and organisation engagement might be different and should be measured as such.

Despite the limitations, this study opens new avenues of research in the relation between CSR and HR, mainly because the concept of engagement is still recent and, as such, there is a lack of understanding on what promotes employee engagement. Moreover, it should be interesting to use a different approach by, for example, measure employees' perception of their company's CSR and the impact it has on their engagement.

The promotion of employee engagement is still a subject that needs further research. Nevertheless, it seems that employees feel highly engaged with companies that care about their customers but also their employees. As such, internal and external practices are two important, yet connected, dimensions of CSR, as shown in the present study. HRD professionals should take this as an opportunity, since several HRD areas, such as training, career development among others are in fact some of the CSR internal practices. Also, they should look at CSR external practices as an argument to promote employees' engagement with HRD activities.

\section{References}

Aguilera, R.V., Rupp, D.E., Williams, C.A. and Ganapathi, J. (2007), "Putting the S back in corporate social responsibility: a multi level theory of social change in organizations", Academy of Management Review, Vol. 32 No. 3, pp. 836-863.

Al-bdour, A.A., Nasruddin, E. and Keng Lin, S. (2010), "The relationship between internal corporate social responsibility and organizational commitment within the banking sector in Jordan”, International Journal of Human and Social Sciences, Vol. 5 No. 14, pp. 932-951. 
Bakker, A.B. and Schaufeli, W.B. (2008), "Positive organizational behavior: engaged employees in flourishing organizations", Journal of Organizational Behavior, Vol. 29 No. 2, pp. 147-154.

Bakker, A.B., Hakanen, J., Demerouti, E. and Xanthopoulou, D. (2007), "Job resources boost work engagement, particularly when job demands are high", Journal of Educational Psychology, Vol. 99 No. 2, pp. 274-284.

Bhattacharya, C.B., Sen, S. and Korschun, D. (2008), "Using corporate social responsibility to win the war for talent”, MIT Sloan Review, Vol. 49 No. 2, pp. 37-44.

Does CSR impact on employee engagement?

Brammer, S., Millington, A. and Rayton, B. (2005), The Contribution of Corporate Social Responsibility to Organizational Commitment, working paper, University of Bath Management School, Bath.

Brickson, S.L. (2005), "Organizational identity orientation: forging a link between organizational identity and organizations' relations with stakeholders", Administrative Science Quarterly, Vol. 50 No. 4, pp. 576-609.

Buchanan, L. (2004), "The things they do for love", Harvard Business Review, Vol. 82 No. 12, pp. 19-20.

Buciuniene, I. and Kazlauskaite, R. (2012), "The linkage between HRM, CSR and performance outcomes", Baltic Journal of Management, Vol. 7 No. 1, pp. 5-24.

Chung, N.G. and Angeline, T. (2010), "Does work engagement mediate the relationship between job resources and job performance of employees?”, African Journal of Business Management, Vol. 4 No. 9, pp. 1837-1843.

Commission of the European Communities (2001), Green Paper: Promoting a European Framework for Corporate Social Responsibility, Commission of the European Communities, Brussels.

Cooke, F.L. and He, Q. (2010), "Corporate social responsibility and HRM in China: a study of textile and apparel enterprises", Asia Pacific Business Review, Vol. 16 No. 3, pp. 355-376.

Czarnowsky, M. (2008), Learning's Role in Employee Engagement: An ASTD Research Study, American Society for Training \& Development, Alexandria, VA.

Davies, I. and Crane, A. (2010), "Corporate social responsibility in small-and medium-size enterprises: investigating employee engagement in fair trade companies", Business Ethics: A European Review, Vol. 19 No. 2, pp. 126-139.

Ferreira, D.A., Avila, M.G. and Faria, M.D. (2010), "Corporate social responsibility and consumers' perception of price”, Social Responsibility Journal, Vol. 6 No. 2, pp. 208-221.

Fleming, J.H. and Asplund, J. (2007), Human Sigma, Gallup, New York, NY.

Freeman, R.E. (1984), Strategic Management: A Stakeholder Approach, Pitman, Boston, MA.

Fuentes-Garcia, F.J. and Nunez-Tabales, J.M. (2008), "Applicability of corporate social responsibility to human resources management: perspective from Spain", Journal of Business Ethics, Vol. 82 No. 1, pp. 27-44.

Garavan, T.N. and McGuire, D. (2010), "Human resource development and society: human resource development's role in embedding corporate social responsibility, sustainability, and ethics in organizations", Advances in Developing Human Resources, Vol. 12 No. 5, pp. 487-507.

Gond, J.-P. and Igalens, J. (2011), "The human resources contribution to responsible leadership: an exploration of the CSR-HR Interface", Journal of Business Ethics, Vol. 98 No. 1, pp. $115-132$.

Greenwood, M. (2007), "Stakeholder engagement: beyond the myth of corporate responsibility", Journal of Business Ethics, Vol. 74 No. 4, pp. 315-327. 
JWL $26,3 / 4$

Hallberg, U. and Schaufeli, W.B. (2006), “'Same same' but different? Can work engagement be discriminated from job involvement and organizational commitment?", European Psychologist, Vol. 11 No. 2, pp. 119-127.

Hansen, D., Dunford, B., Boss, A., Boss, R. and Angermeier, I. (2011), "Corporate social responsibility and the benefits of employee trust: a cross-disciplinary perspective", Journal of Business Ethics, Vol. 102 No. 1, pp. 29-45.

Harter, J.K., Schmidt, F.L. and Keyes, C.L.M. (2003), "Wellbeing in the workplace and its relationship to business outcomes: a review of the Gallup studies", in Keyes, C.L. and Haidt, J. (Eds), Flourishing: The Positive Person and the Good Life, American Psychological Association, Washington, DC, pp. 205-224.

Kahn, W. (1990), "Psychological conditions of personal engagement and disengagement at work", Academy of Management Journal, Vol. 33 No. 4, pp. 692-724.

Kakabadse, N.K., Rozuel, C. and Lee-Davies, L. (2005), "Corporate social responsibility and stakeholder approach: a conceptual review", International Journal Business Governance and Ethics, Vol. 1 No. 4, pp. 277-302.

Kanungo, R.N. (1979), "The concepts of alienation and involvement revisited", Psychological Bulletin, Vol. 86 No. 1, pp. 119-138.

Kotler, P. and Lee, N. (2005), Corporate Social Responsibility: Doing the Most Good for Your Company and Your Cause, Wiley, Hoboken, NJ.

Lindgreen, A. and Swaen, V. (2010), "Corporate social responsibility", International Journal of Management Reviews, Vol. 12 No. 1, pp. 1-7.

Little, B. and Little, P. (2006), "Employee engagement: conceptual issues", Journal of Organizational Culture, Communications and Conflict, Vol. 10 No. 1, pp. 111-120.

McWilliams, A., Siegel, D. and Wright, P. (2006), "Corporate social responsibility: strategic implications", Journal of Management Studies, Vol. 43 No. 1, pp. 1-18.

Macey, W. and Schneider, B. (2008), "The meaning of employee engagement", Industrial and Organizational Psychology, Vol. 1 No. 1, pp. 3-30.

Maon, F., Lindgreen, A. and Swaen, V. (2009), "Designing and implementing corporate social responsibility: an integrative framework grounded in theory and practice", Journal of Business Ethics, Vol. 87 No. 1, pp. 71-89.

Marchese, M.C. and Bassham, G. (2002), "Work-family conflict: a virtue ethics analysis", Journal of Business Ethics, Vol. 40 No. 2, pp. 145-154.

Maslach, C., Schaufeli, W.B. and Leiter, M.P. (2001), "Job burnout”, Annual Review of Psychology, Vol. 52, pp. 397-422.

Mirvis, P. (2012), "Employee engagement and CSR: transactional, relational, and developmental approaches", California Management Review, Vol. 54 No. 4, pp. 93-117.

Newman, C.J. and de Vries, D.H. (2011), "Workplace violence and gender discrimination in Rwanda's health workforce: increasing safety and gender equality”, Human Resources for Health, Vol. 9 No. 19, pp. 1-13.

Ouweneel, E., Blanc, P. and Schaufeli, W.B. (2012), "Don't leave your heart at home: gain cycles of positive emotions, resources, and engagement at work", Career Development International, Vol. 17 No. 6, pp. 537-556.

Petrou, P., Demerouti, E., Peeters, M., Schaufeli, W.B. and Hetland, J. (2012), “Crafting a job on a daily basis: contextual correlates and the link to work engagement", Journal of Organizational Behavior, Vol. 33 No. 8, pp. 1120-1141. 
Preuss, L. and Haunschild, A. (2009), "The rise of CSR: implications for HRM and employee representation”, International Journal of Human Resource Management, Vol. 20 No. 4, pp. 953-973.

Real de Oliveira, E. and Rodrigues, P. (2012), “The importance of corporate social responsibility in the brand image - the Nespresso case study", Proceedings of the UFHRD 2012 - 13th International Conference on HRD Research Practice Across Europe: The Future of HRD 2020 and Beyond: Challenges and Opportunities, CLEGI, Vila Nova de Famalicao, pp. 756-763.

Does CSR impact on employee engagement?

247

Real de Oliveira, E., Ferreira, P. and Saur-Amaral, I. (2013), "Human resource management and corporate social responsibility: a systematic literature review", Journal of Knowledge Economy \& Knowledge Management, Vol. 8, Spring, pp. 47-62.

Rettab, B., Brik, A. and Mellahi, K. (2009), "A study of management perceptions of the impact of corporate social responsibility on organisational performance in emerging economies: the case of Dubai”, Journal of Business Ethics, Vol. 89 No. 3, pp. 371-390.

Rowley, T. and Berman, S. (2000), “A brand new brand of CSP”, Business \& Society, Vol. 39 No. 4, pp. 397-418.

Rupp, D., Ganapathi, J., Aguilera, R. and Williams, C. (2006), "Employee reaction to corporate social responsibility: an organizational justice framework", Journal of Organizational Behaviour, Vol. 27 No. 4, pp. 537-543.

Saks, A.M. (2006), "Antecedents and consequences of employee engagement", Journal of Managerial Psychology, Vol. 21 No. 7, pp. 600-619.

Salanova, M. and Schaufeli, A.B. (2008), "A cross-national study of work engagement as a mediator between job resources and proactive behavior", The International Journal of Human Resource Management, Vol. 19 No. 1, pp. 116-131.

Salanova, M., Agut, S. and Peiro, J.M. (2005), "Linking organizational resources and work engagement to employee performance and customer loyalty: the mediation of service climate", Journal of Applied Psychology, Vol. 90 No. 6, pp. 1217-1227.

Salanova, M., Lorente, L., Chambel, M.J. and Martinez, I.M. (2011), "Linking transformational leadership to nurses' extra-role performance: the mediating role of self-efficacy and work engagement", Journal of Advanced Nursing, Vol. 67 No. 10, pp. 2256-2266.

Schaufeli, W.B., Bakker, A.B. and Salanova, M. (2006), "The measurement of work engagement with a short questionnaire. A cross-national study", Educational and Psychological Measurement, Vol. 66 No. 4, pp. 701-716.

Schaufeli, W.B., Salanova, M., González-Romá, V. and Bakker, A.B. (2002), “The measurement of engagement and burnout: a two sample confirmatory factor analytic approach", Journal of Happiness Studies, Vol. 3 No. 1, pp. 71-92.

Schneider, B., Erhart, M., Mayer, D., Saltz, J. and Niles-Jolly, K. (2005), "Understanding organization-customer links in service settings", Academy of Management Journal, Vol. 48, pp. 1017-1032.

Scott, S.G. and Lane, V.R. (2000), "A stakeholder approach to organizational identity”, Academy of Management Review, Vol. 25 No. 1, pp. 43-62.

Sen, S. and Bhattacharya, C.B. (2001), "Does doing good always lead to doing better? Consumer reactions to Corporate Social Responsibility", Journal of Marketing Research, Vol. 38 No. 2, pp. 225-243.

Shen, J. (2011), "Developing the concept of socially responsible international human resource management", International Journal of Human Resource Management, Vol. 22 No. 6, pp. 1351-1363. 
JWL $26,3 / 4$
Shen, J. and Zhu, C.J. (2011), "Effects of socially responsible human resource management on employee organizational commitment", International Journal of Human Resource Management, Vol. 22 No. 15, pp. 3020-3035.

Shuk, B. and Wollard, K. (2010), "Employee engagement and HRD: a seminal review of the foundations", Human Resource Development Review, Vol. 9 No. 1, pp. 89-110.

Tajfel, H. and Turner, J.C. (1985), "The social identity theory of intergroup behavior”, in Worchel, S. and Austin, W.G. (Eds), Psychology of Intergroup Relations, 2nd ed., Nelson Hall, Chicago, IL, pp. 7-24.

Tamm, L., Eamets, R. and Mõtsmees, P. (2010), Relationship Between Corporate Social Responsibility and Job Satisfaction: The Case of Baltic Countries, The University of Tartu, Tartu.

Turker, D. (2009), "Measuring corporate social responsibility: a scale development study", Journal of Business Ethics, Vol. 85 No. 4, pp. 411-427.

Vance, R.J. (2006), Employee Engagement and Commitment: A Guide to Understanding, Measuring, and Increasing Engagement in Your Organization, The SHRM Foundation, Alexandria, VA.

Viljevac, A., Cooper-Thomas, H. and Saks, A.M. (2012), “An investigation into the validity of two measures of work engagement", The International Journal of Human Resource Management, Vol. 23 No. 17, pp. 3692-3709.

Wagner, R. and Harter, J.K. (2006), 12: The Great Elements of Managing, The Gallup Organization, Washington, DC.

Wojtaszczyk, P. (2008), "The role of workplace health promotion in the concept for corporate social responsibility”, Medycyna Pracy, Vol. 59 No. 3, pp. 255-261.

Wood, D.J. and Jones, R.E. (1995), "Stakeholder mismatching: a theoretical problem in empirical research in corporate social performance", International Journal of Organizational Analysis, Vol. 3 No. 3, pp. 229-267.

Young, S. and Thyil, V. (2009), "Governance, employees and CSR: integration is the key to unlocking value”, Asia Pacific Journal of Human Resources, Vol. 47 No. 2, pp. 167-185.

\section{Further reading}

Skritsovali, K. (2013), "What is the relationship between CSR and employee engagement?”, RIBM Doctoral Symposium 2013.

\section{About the authors}

Pedro Ferreira is Assistant Professor at Lusiada University and Professor at Portuguese Institute of Marketing Management. He holds a $\mathrm{PhD}$ in Economics and his research interests include comparative HRM, employee engagement, and employer branding. He has 15 years' experience in teaching in marketing, human resources management and research methods related issues. Pedro Ferreira is the corresponding author and can be contacted at: pedroferreira@fam.ulusiada.pt

Elizabeth Real de Oliveira is Dean of Faculty of Business and Economics of Lusiada University. She holds a $\mathrm{PhD}$ in Management by the University of South Wales (former University of Glamorgan). Her research interests include corporate social responsibility, HRM, employee engagement and employer branding. She has a wide experience as professor and consultant.

To purchase reprints of this article please e-mail: reprints@emeraldinsight.com Or visit our web site for further details: www.emeraldinsight.com/reprints 